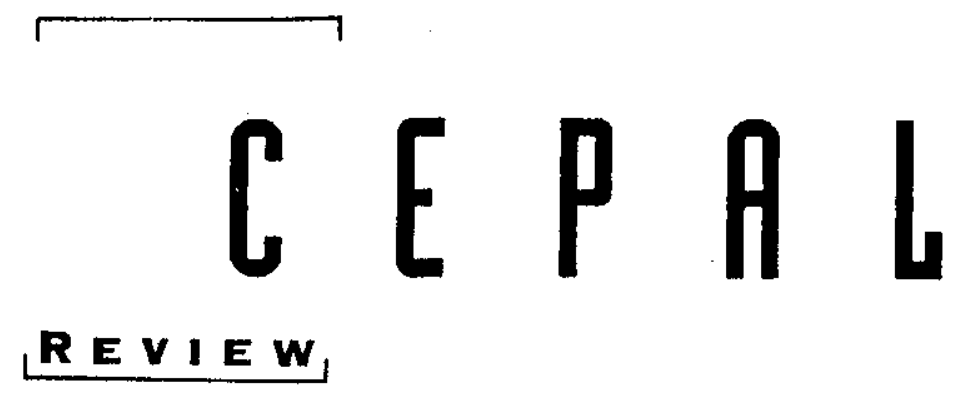

\author{
NUMBER 65 \\ AUGUST 1998 \\ SANTIAGO, CHILE \\ O S CAR ALTIMIA \\ Director of the Review \\ EUGENIO LAHERA \\ Technical Secretary
}

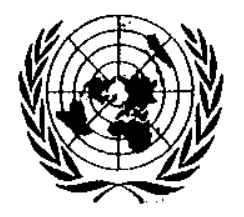


Income distribution, poverty and social expenditure in LatIn America

José Antonio Ocampo

Military expenditure and development in Latin America

Eugenio Lahera and Marcelo Ortúzar

Growth, dlstributive Justice and social policy

Andrés Solimano

Equity, foreign investment and international competitiveness

Adolfo Figueroa

Tensions in Latin American structural adjustment:

allocation versus distribution

Daniel M. Schydlowsky

Competitiveness and labour regulations

71

Luis Beccaria and Pedro Galín

Latin American families: convergences and divergences in models and pollcies

Irma Arriagada

Free trade agreements and female labour: the Chilean situation Alicia Frohmann and Pilar Romaguera

Macroeconomic trends in Paraguay from 1989 to 1997: consumption bubble and financial crisis Stephane Straub

The strategies pursued by Mexican firms in their efforts to become global players

Alejandra Salas-Porras

Regulating the private provision of drinking water and sanitation services

Terence $R$. Lee and Andrei S. Jouravlev

Quallty management promotion to improve competitiveness

Hessel Schuurman

Recent ECLAC publications 


\section{Growth, distributive justice and social policy}

\section{Andrés Solimano}

Subregional Director for Colombia, Ecuador and Venezuela, World Bank.

\begin{abstract}
After more than a decade of economic reform and structural adjustment in the developing countries, there is increased recognition that economic growth and social equity must go hand in hand. This article starts by asking what is meant by "social equity". It notes that reduction of poverty and improvement of income distribution are two perfectly complementary policy objectives, since less inequality can help both to reduce poverty and to speed up economic growth. It reviews the main elements of the modern theory of distributive justice, covering the ethical and economic dimensions of inequality. It then turns to the recent analytical and empirical literature on the relationship between growth, inequality and development and addresses the question of whether is it possible to have both sustained economic growth and a simultaneous reduction in social inequality. It also focuses on social policies and discusses the scope and limits of growthdriven poverty reduction, targeting of social programmes and private sector participation in the provision of social services, highlighting the role of education, broader access to credit, more democratic ownership of productive assets (land; stocks and shares), and popular participation in the management of social policies as necessary means of making sustained growth compatible with distributive justice.
\end{abstract}




\section{I}

\section{Introduction}

After more than a decade of economic reform and structural adjustment in the developing countries, there is increased recognition that economic growth and social equity must go hand in hand. Economic growth is essential in order to improve living standards, generate employment and reduce poverty. In addition, growth generates income for the government, through taxation, that can be spent on social programmes. However, growth is generally unable, per se, to correct large income and wealth inequalities that can affect macro and social stability and therefore undermine the growth process.

In the 1990s there has been a proliferation of analytical studies on the relationship between income distribution (social inequality) and economic growth which explore the nature, sign and causality directions of the relation between these variables, as well as the transmission mechanisms at work. In addition, a reassessment of the Kuznets curve, the empirical relationship between levels of inequality and development, is underway.

Perhaps surprisingly, the recent academic interest in income distribution, growth, and development has not been matched by equivalent interest or action at the policy level. In fact, social policy is often defined as an anti-poverty strategy, with income distribution considerations remaining as an implicit (or even ambiguous) objective in the policy agenda of international institutions and governments.

The paper starts by asking what is meant by "social equity", distinguishing between poverty and income distribution as two somewhat different but complementary policy targets, since less social inequality can help to attain both a lower level of poverty and a higher rate of economic growth.

After dealing with the main elements of the modern theory of distributive justice, which takes into account the ethical, philosophical and economic dimensions of inequality, the paper turns to the recent analytical and empirical literature on the relationship between growth, inequality and development and addresses the question of whether is it possible to pursue sustained economic growth at the same time as reduced social inequality.

The paper also focuses on social policies and discusses the scope and limits of growth-driven poverty reduction, targeting of social expenditure, and private sector participation in the provision of social services, highlighting the role of education, health, broader access to bank credit and ownership of productive assets (land, stocks and shares, etc.) and popular participation in the management of social policies as ways to increase equality, foster social mobility and enhance productivity, all of which are necessary elements for the integral reduction of poverty.

\section{II}

\section{Poverty and inequality:}

\section{what do we mean by social equity?}

What we might call a minimalist approach views the reduction of absolute poverty as the only valid concern for social policy, holding that public policy must assure that most of (or ideally all) the population is above the poverty line and that no vulnerable groups

$\square$ The author wishes to express his gratitude to Louis Emmerij and Mario Gutiérrez for their valued comments on a preliminary version of this paper. (the elderly, children, poor households) suffer income deprivation. According to this view, as society reaches a threshold of basic needs satisfied for the population as a whole, subsequent inequalities could be considered as largely irrelevant.

The extent to which the reduction of social inequality is a valid additional policy objective (besides poverty reduction) is a complex issue related to 
at least two considerations: i) ethical and moral questions of distributive justice which may make the reduction of inequality an objective in itself; and ii) the impact of income inequality on other policy objectives such as sustained economic growth, socio-political stability, and the capacity to direct and implement public policies aimed at furthering development.

\section{III}

\section{The theory of distributive justice}

The theory of distributive justice ${ }^{1}$ focuses on the causes of inequality and provides the philosophical and economic foundations to illuminate discussions on inequality.

\section{External factors and personal responsibility}

If the inequalities of income and wealth observed in a society reflect to a large extent differences in initial endowments of wealth, talent, family connections, race or gender -factors which are mostly beyond the control of the individual and therefore represent (in philosophical terms) a set of "morally arbitrary" factors- then inequality becomes an ethical issue, since key wealth-creating factors are "external" to the individual. However, observed inequalities of income, wealth and consumption can and do also reflect individual differences in effort, ambitions and risk-taking. To the extent that these latter elements reflect personal preferences and belong to the realm of personal responsibility, they do not necessarily constitute an ethical problem from the viewpoint of distributive justice.

This neat distinction between "external" factors and those belonging to the realm of individual responsibility is blurred when it is recognized that "external" or "morally arbitrary" factors (e.g., initial wealth or talent) are likely to be related to the formation of preferences and the concept of individual responsibility, for individual preferences that ultimately guide efforts, ambitions and risk-taking are influenced by the resources and talents owned (or available) to the individual; in fact, it may well be thought that a wealthy individual's perception of what constitutes "success in life" or acceptable levels of welfare

\footnotetext{
${ }^{1}$ For a study on recent theories of distributive justice, see Solimano (ed.), 1998, chapter 2; see also Roemer, 1996.
}

can be very different from those of the poor or handicapped. This circularity between resources and preferences or between "morally arbitrary factors" and "personal responsibility" makes the theme of the origins of social inequality both exciting and highly complex.

\section{Alternative views on distributive justice and social Inequality}

The fundamentally different visions of society held by the different schools of thought affect views on inequality. Important liberal thinkers such as John Rawls emphasize that initial wealth, family background, social connections and the like can be unfairly distributed in the "birth-lottery". For Rawls (1971), the organization of a just society requires a social contract negotiated by the different social actors under a "veil of ignorance" regarding the distribution of wealth and other traits among individuals that shapes their interests in society, and a social arrangement is just only if it is the best for those relatively worse-off in society, compared to other alternative social arrangements (the so-called "difference principle").

In the neoclassical and utilitarian approaches, welfare economics avoids judging the justice of a given distribution of income and wealth in society by focusing only on maximizing the total sum of personal utilities, regardless of how those utilities are distributed among the different members of society. Moreover, neoclassical economics sees distributive outcomes as the result of voluntary wealth accumulation over generations, with the remuneration of factors of production being given by the levels of productivity and effort, rather than being determined by features outside personal control and responsibility, as emphasized in the theory of distributive justice. 
Box 1

DETERMINANTS OF INCOME AND WEALTH AND CONCEPTS OF EQUALITY

\begin{tabular}{lcc}
\hline $\begin{array}{c}\text { Determinants of } \\
\text { income and wealth }\end{array}$ & $\begin{array}{c}\text { Initial assets: talent, } \\
\text { gender, race, family status } \\
\text { ("outside" factors or } \\
\text { initial conditions) }\end{array}$ & $\begin{array}{c}\text { Effort levels, risk-taking } \\
\text { entrepreneurial } \\
\text { capacities }\end{array}$ \\
\hline Equality of opportunities & $\mathrm{X}$ & (personal responsibility) \\
Equality of outcomes & $\mathrm{X}$ & $\mathrm{X}$ \\
\hline
\end{tabular}

Marxian economics, for its part, sees the unequal property relations and command of productive wealth in capitalism as the main factors responsible for generating and reproducing existing inequalities over time (Marx, 1970). In contrast, libertarians like Robert Nozick see the possession of wealth and the right to enjoy its benefits as a natural right of the individual, as part of the "self-ownership" that includes the right of private use of productive assets and natural resources (Cohen, 1995).

\section{Concepts of equality}

Another important set of issues in the theory of distributive justice relates to the concept of equality. ${ }^{2}$ A crucial distinction is made between equality of opportunities and equality of outcomes: a person may not be responsible for the set of opportunities he faces when he is born -race, gender, talent, wealth and family background are all predetermined variables for the individual- but each person is responsible for transforming favourable opportunities into positive outcomes. Equality of access to wealthcreating factors (e.g., education or credit) is termed equality of opportunities, and would be a valid policy objective from the viewpoint of distributive justice. In contrast, setting the objective of distributive justice in terms of equality of outcomes, measured by income or wealth, should not necessarily be a target for social policies if outcomes depend to a considerable extent on voluntary choices regarding effort in the workplace and/or risk-taking attitudes in undertaking entrepreneurial activities (box 1).

The (minimalist) view postulating equality of opportunities as the only valid criterion for a distributive policy circumvents the fact that effort and risk-taking are not fully independent of initial background conditions, as already noted, however. A more "activist" view of equality would qualify the concept of equality of opportunities and expand it in several directions: first, it would distinguish between formal and effective equality of opportunities (for example, education might be a universal right in a country, but effective access to it may depend on the income level of the student), and second, it would call for compensation of those relatively less lucky in the "birth-lottery" (for reasons of less talent, race and gender, or vulnerability to discrimination). The implementation of compensation schemes will entail policies of income transfers, affirmative actions and others that go beyond the idea of pursuing only equality of opportunities to equalize access to education, credit or other resources, without seeking to compensate for other background conditions that are important for future individual success in life.

${ }^{2}$ A telling analysis which has influenced philosophical economics in this regard may be found in Dworkin, 1981. 


\section{IV}

\section{Inequality, growth and development: Complementarities and trade-offs}

Let us now move from the complicated questions of distributive justice to the macro interactions (tradeoffs and/or complementarities) between inequality, economic growth and long-term development. Is inequality of income and wealth the price to be paid for accelerated economic growth? Or, conversely, does inequality retard economic growth? How does inequality evolve during the course of economic development? These are key questions that need to be addressed.

\section{Llnks between growth and Inequallty}

The relationship between economic growth and social inequality at the macro level depends on how the growth process is specified. ${ }^{3}$ In models of savingdriven growth, if profits-recipients save in greater proportion than wage-earners (linear saving functions), a pattern of income distribution more concentrated towards capital will increase national saving and accelerate the economic growth rate (everything that is saved is invested). This model supported the "conservative" notion that a more equitable distribution of income retards economic growth through its negative effect on the national savings ratio, thus pointing to the existence of a trade-off between growth and equity.

Conversely, neo-Keynesian and endogenous growth theories view growth mainly as an investment-driven process and emphasize complementarities between growth and social equality. In neo-Keynesian models in which aggregate demand plays a role in the determination of long-term growth, income distribution affects growth through both effective demand (consumption, investment demand, exports) and the rate of creation of new productive capacity.

\footnotetext{
${ }^{3}$ See Solimano (ed.), 1998, chapter 4; Solimano (forthcoming, chapter 2), and Alesina and Rodrik, 1994.
}

A redistribution of income to wage-earners can raise aggregate demand and growth in the short term provided positive consumption effects predominate over adverse effects on investment and exports. However, that initial increase in aggregate demand will probably lead to supply constraints, generating inflationary and balance-of-payments disequilibria that will limit or simply reverse the initial income redistribution. ${ }^{4}$ In the endogenous growth literature, countries with large personal income and wealth inequalities invite, through a political mechanism, higher taxation and the adoption of redistributive policies that depress the profitability of capital, hampering investment and slowing down growth of the product, the main implication therefore being that initial inequality is bad for subsequent growth. Other channels have also been highlighted to show a negative correlation between personal income inequality and economic growth: inequality can lead to sociopolitical instability and/or to populist economic policies that are ultimately destabilizing and hamper private capital formation and economic growth. In analytical terms, the new literature combines investment-driven growth with a political mechanism causing public preferences for pro-growth rather than pro-redistribution policies to be reflected in actual government policies. This political mechanism ranges from elections or referendums to social pressure (e.g. social activism, strikes, etc.). In the endogenous growth, neo-Keynesian and neo-marxist models the causality goes from initial inequality to future growth (table 1). Interestingly, this literature carries a "progressive" message that social inequality is bad for growth, although it identifies redistributive policies (particularly those that hamper investment) as the reason why initial inequality brings subsequent slower growth.

\footnotetext{
${ }^{4}$ This was the case with the redistributive policies pursued by Allende in Chile in the early 1970s, by Nicaragua in the early 1980 s, and by Peru in the mid-1980s.
} 
TABLE

Summary of distribution and growth theories

\begin{tabular}{|c|c|c|c|c|c|c|c|c|c|c|}
\hline \multirow[b]{2}{*}{ Theories } & \multicolumn{2}{|c|}{ Model } & \multicolumn{2}{|c|}{$\begin{array}{l}\text { Economic } \\
\text { mechanism }\end{array}$} & \multicolumn{2}{|c|}{$\begin{array}{l}\text { Socio-political } \\
\text { mechanism }\end{array}$} & \multicolumn{2}{|c|}{ Causality } & \multicolumn{2}{|c|}{$\begin{array}{l}\text { Type of relationship } \\
\text { between inequality } \\
\text { and growth }\end{array}$} \\
\hline & $\begin{array}{l}\text { Saving- } \\
\text { driven } \\
\text { growth }\end{array}$ & $\begin{array}{l}\text { Invest- } \\
\text { ment- } \\
\text { driven } \\
\text { growth }\end{array}$ & $\begin{array}{l}\text { Through } \\
\text { classic } \\
\text { saving } \\
\text { function }\end{array}$ & $\begin{array}{l}\text { Through } \\
\text { profit- } \\
\text { ability } \\
\text { and } \\
\text { invest- } \\
\text { ment }\end{array}$ & $\begin{array}{l}\text { Median } \\
\text { voter }\end{array}$ & $\begin{array}{l}\text { Bargain- } \\
\text { ing } \\
\text { power } \\
\text { of capi- } \\
\text { talists/ } \\
\text { workers }\end{array}$ & $\begin{array}{l}\text { Income } \\
\text { distri- } \\
\text { bution } \\
\text { to } \\
\text { growth }\end{array}$ & $\begin{array}{l}\text { Growth } \\
\text { to } \\
\text { income } \\
\text { distri- } \\
\text { bution }\end{array}$ & Inverse & Direct \\
\hline Classic & $\mathrm{X}$ & & $\mathrm{X}$ & & & & $\mathrm{x}$ & & & $\mathrm{X}$ \\
\hline Solow & $\mathrm{X}$ & & & & & & & $\mathrm{X}$ & & \\
\hline Kaldor & & $\mathbf{x}$ & $\mathrm{X}$ & & & & & $\mathbf{X}$ & & $\mathbf{X}$ \\
\hline $\begin{array}{l}\text { New growth theory/ } \\
\text { endogenous policy }\end{array}$ & & $X$ & & $\mathrm{X}$ & $\mathrm{X}$ & & $X$ & & $X$ & \\
\hline $\begin{array}{l}\text { Wage-led and profit-led } \\
\text { growth theories } \\
\text { (neo-Keynesian) }\end{array}$ & & & $\mathrm{X}$ & $\mathrm{X}$ & & & $\mathrm{X}$ & $\mathrm{X}$ & & \\
\hline $\begin{array}{l}\text { Neo-Marxist theories } \\
\text { a) Long-run } \\
\text { b) Profits squeeze/ } \\
\text { social structures } \\
\text { of accumulation }\end{array}$ & $\mathrm{X}$ & $\mathrm{X}$ & $\mathbf{X}$ & $\mathbf{X}$ & & $X$ & $\mathrm{X}$ & & & $\mathrm{X}$ \\
\hline
\end{tabular}

Source: Solimano, 1998, chapter 4.

\section{Empirical evidence}

The empirical part of this literature on the relationship between inequality and growth is largely dominated by cross-section or panel regression analysis. ${ }^{5}$ In general, a number of empirical studies tend to support the hypothesis that inequality (an explanatory variable) has an often statistically significant negative effect on the rate of product growth (the dependent variable in the regressions) after controlling by variables such as initial per capita income, levels of education, and political participation. This result seems to hold for separate samples of developed and less developed economies (Persson and Tabellini, 1992) and is robust for various alternative functional forms of the distribution-growth relationship and different measures of inequality (share of top quintile, Gini coefficient, Theil coefficient (see Clarke, 1992)).

\footnotetext{
${ }^{5}$ In the studies on distribution and growth it is still hard to find analyses of time series with institutional and historical information from the countries studied.
}

However, not all studies agree on this. For example, Fishlow (1995) shows that the negative correlation between inequality and growth ceases to be detected when a dummy variable for Latin America -a region with high inequality- is included in the regressions. There seems to be even less agreement on the influence of the political regime (democracies or non-democracies) on the inequality/growth nexus. While Persson and Tabellini (1992) found that the negative relationship between inequality and growth holds only for democracies, Clarke (1992) and Alesina and Rodrik (1994) found no significant impact of the political regime on the sign and significance of the distribution parameter in the growth regressions. It is worth mentioning that all the models tested which include the economic and political mechanisms are reduced forms. A structural test of the political mechanism (median voter) proposed in the theory is hard to find.

A recent World Bank study by Deininger and Squire (1995b) shows that most of the recent tests of the negative relationship between initial inequality and subsequent economic growth are based on in- 
come distribution data of limited coverage, with little cross-country and temporal comparability. Moreover, the results obtained in those previous studies have to be carefully interpreted as they are estimates from reduced forms of a structural model in which other variables may determine the joint co-movement of growth and income distribution observed in the data. Furthermore, in a related study Liu, Squire and Zou (1995), using recent and more consistent data on income distribution, show that income inequality is relatively stable within countries and over time, in stark contrast with the behaviour of the rates of growth of GDP, which change rapidly and are characterized by very low persistence. These two studies strongly caution about the accuracy of the empirical tests of the new growth theory on income inequality.

\section{Links between inequallty and development: the Kuznets curve}

The relationship between levels of development (proxied by the level of per capita income and total income) and inequality (measured by the Gini coefficients or the relative shares of the top and bottom quintiles or deciles) postulated by Simon Kuznets has been the subject of controversy and empirical testing for a long time. As it is well known, the Kuznets hypothesis states the existence of a non-linear relationship between per capita income and an index of income inequality, reflected in an inverted U-curve; income inequality worsens in the initial stages of development, characterized by low per capita income levels, but improves thereafter as per capita income rises (figures 1 and 2). The Kuznets mechanisms focused on the shift from a surplus-labour agricultural sector paying subsistence wages to a modern industrial sector with higher wages during the initial stages of development. Later on, inequality declines due to a narrowing of wage differentials as the pool of surplus labour is exhausted and the skills profile of the work-force is upgraded through formal education and learning-by-doing during the course of development. According to Kuznets, the causality goes from development levels to inequality, and the sign of the relationship evolves over historical time.

\section{Empirical evidence}

The Kuznets curve spurred a vast empirical effort devoted to testing its shape, determining its robustness to the selection of countries and time periods, and detect-
FIGURE 1

The Kuznets curve: Representative International sample of $\mathbf{6 0}$ countries for the 1960 s and $1970 \mathrm{~s}$

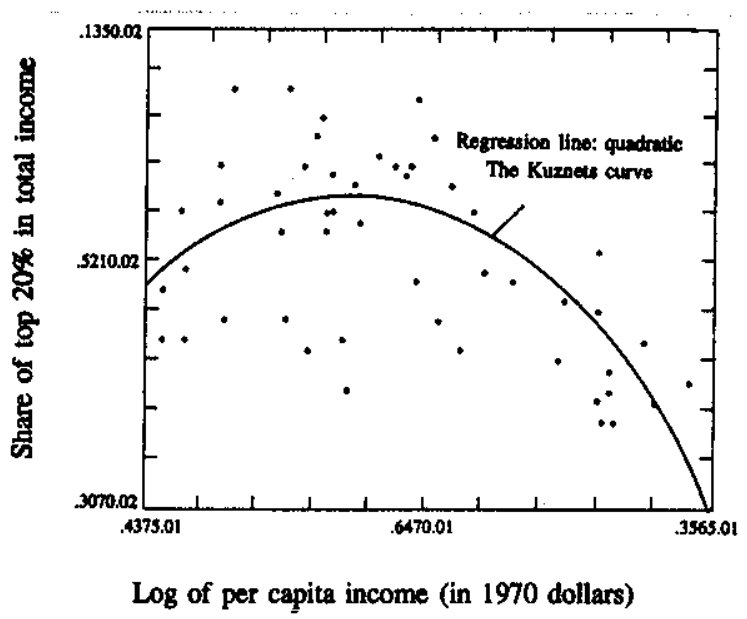

Source: Ahluwalia, 1976, table 8, pp. 340-341.

ing turning points at which income distribution starts improving along the development process.

The empirical cross-section analyses of Ahluwalia (1976), Lindert and Williamson (1985), Adelman and Robinson (1989), Bourguignon and Morrison (1990) and others tend to give (qualified) support to the existence of the Kuznets curve. In addition, for crosscountry regressions, the inequality portion of the Kuznets curve tends to be more unstable than the portion of declining inequality (see figure 1). Since the inequality part of the curve comprises countries in a range of low to moderate per capita income levels, the relationship is more unstable for these countries. ${ }^{6}$ In contrast, it seems a more established fact that inequality tends to decline in countries at the intermediate and high levels of per capita income (see figure 2$)^{7}$.

\footnotetext{
${ }^{6}$ A recent study by Fields and Jakubson (1993) found an inversion of the Kuznets curve in a "fixed effects" model allowing different countries to fit into Kuznets curves with the same shape but different intercepts. In models combining time series with cross-sectional analyses, however, the standard Kuznets curve is maintained.

${ }^{7}$ This does not rule out changes in the levels of inequality even in high per capita income countries as the result of changes in economic policies. This seems to be the case for the United States under President Reagan and the United Kingdom under Prime Minister Thatcher, where inequality went up (see Krugman, 1994).
} 
FIGURE 2

The Kuznets curve: Historlcal time serles from

five European countrles and the United States

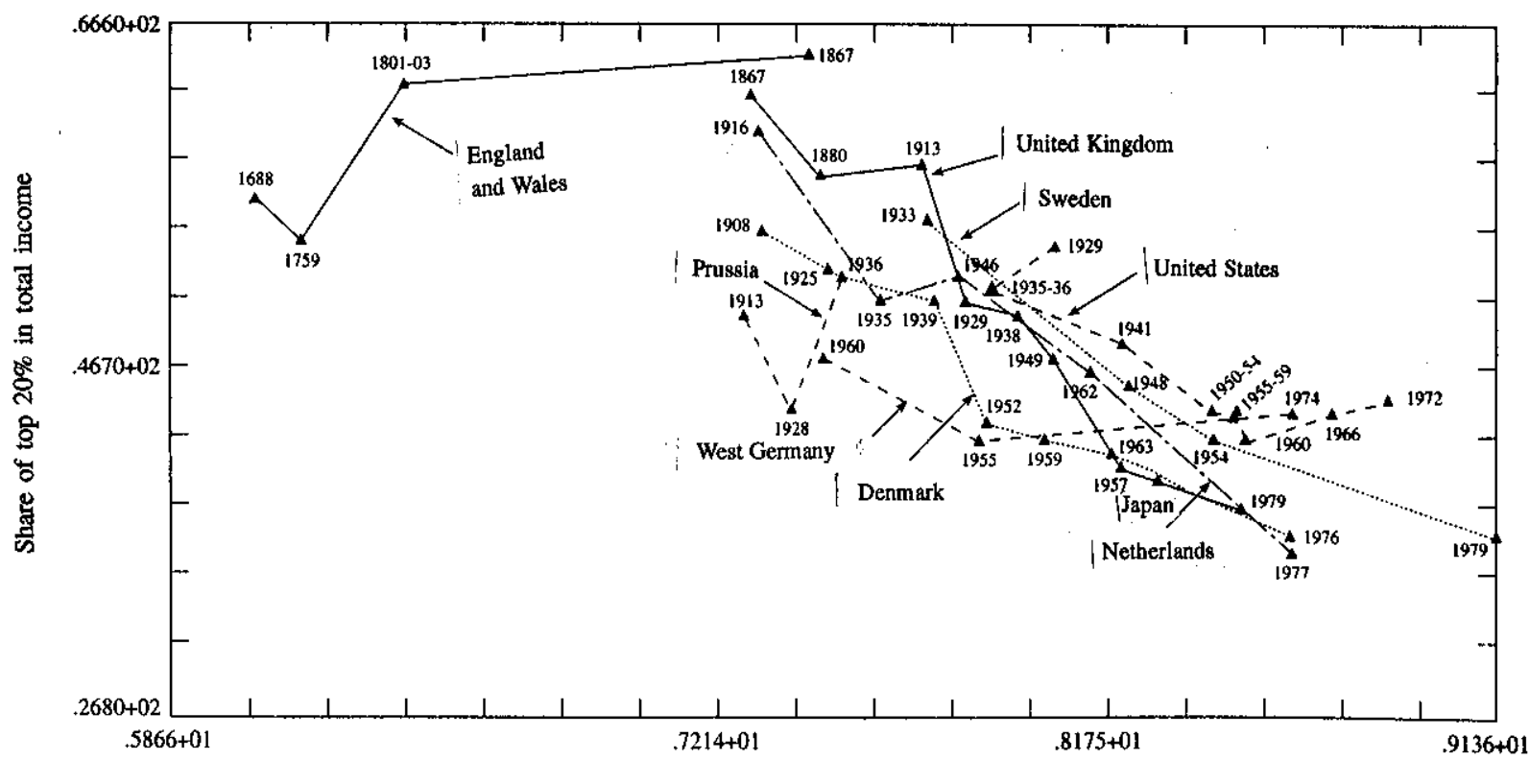

Log of per capita income (in 1970 dollars)

Source: Lindert and Williamson, 1985.

However, studies for some individual countries in Latin America (Colombia, Brazil, Argentina) and for Asian countries are reported to conform to the Kuznets curve pattern (see Fields and Jakubson, 1993). A comparison of the impact of inequality on growth in Latin America and in East Asia is made in Birdsall and Sabot (1994).

Two recent World Bank studies (Deininger and Squire, 1995a and 1995b) have produced a new expanded data-base on income distribution, giving improved coverage and consistency for the re-evaluation of existing studies of the Kuznets curve. These World Bank studies, which pool cross-sectional with timeseries data, show that the Kuznets curve holds only for a very small set of countries ( $10 \%$ of the sample) and that in general no statistically significant relationship between the level of income and inequality is found for over $75 \%$ of the sample. The "universal Kuznets curve" is not detected in the data. These recent studies thus cast doubts on the existence and robustness of the Kuznets curve. More research is needed to settle the conflict between the new World Bank observations and previous evidence on the Kuznets curve. At all events, there seems to be evidence that as countries move up the per capita income ladder, inequality tends to decline. An important practical question is at what levels of per capita income (US\$ 5,000 ?, US\$ 8,000 ?) income inequality starts to decline, and how public policies can help accelerate this process. 


\section{V}

\section{Policy issues}

\section{Are growth and equality compatible?}

A central question is whether public policies aimed at improving income distribution can be compatible with high and sustained growth. The macro-growth models reviewed here offer arguments in support both of "conservative" views that redistribution deters growth and "progressive" views that redistribution and growth are compatible and even mutually reinforcing complementary policy goals. Analytically, the conservative view finds support in two models. In a full-capacity, growing economy, income redistribution to relatively low-saving groups can depress the aggregate saving ratio, thus leading to a decline in growth. In investment-driven models, redistributive policies that entail higher taxation and/or regulation depress privately appropriated returns on human capital and physical investment and harm growth. Are we thus condemned to accept social inequality as the price for high-growth policies? Is the "conservative equilibrium" inescapable? Not necessarily. Three arguments are in order here:

First, the message of the Kuznets curve is that the growth process itself would be "equalizing" beyond a certain threshold of per capita income (the turning point of the curve), making the fruits of progress and development available to a greater portion of the population.

Second, beyond trickle-down, policy intervention to assure broad social access to education (and to credit) can have a big pay-off in terms of both efficiency and equity. The market equilibrium can lead to substantial underinvestment, particular in human capital, in the case of those at the bottom part of the income distribution scale who cannot pay for their education and have very limited access to capital markets. Accelerated widening of the educational base is a policy with great potential for making growth compatible with equity.

Third, a more equitable distribution of income and economic opportunities also contributes to social peace and political stability, which are key ingredients in a policy framework conducive to investment, innovation and growth. In the final analysis, social equity and economic growth can go hand in hand if properly articulated to respect the key economic and political constraints affecting society.

\section{Growth and poverty reduction in a market- based framework: scope and limits}

In line with market-based economic reform, during the last decade many countries have moved away from traditional social policies that often involved across-the-board subsidies to large segments of the population on basic foodstuffs, public utilities such as water and electricity and other social services. For a while, in many countries these policies made possible a considerable reduction in illiteracy, substantial educational upgrading of the middle class and lower income groups, and improvement in health indicators. However, these policies eventually led to a growing fiscal burden and they often also benefited higher income groups.

The new social policies tailored to a market-based policy framework rest on the following principles:

- Economic growth should be the main engine for poverty reduction and improvement in living standards (the "trickle-down" effect).

- Relative prices and the market mechanism must guide resource allocation and the incentives to save and invest. Social policies must avoid affecting the relative price structure of the economy through subsidies and indirect taxation. Price controls of basic foodstuffs must be eliminated. Marginal cost pricing must dictate charges to users of public utilities.

- Social policies must be explicitly focused on -or targeted to- the most vulnerable segments of the population (the elderly, children, the handicapped) and the poorest groups in society (the rural population, workers in the informal sector, families in extreme poverty in urban dwellings).

- Private sector participation in the provision and management of basic social services such as education and health must be encouraged through privatization and/or concession schemes.

- The explicit objective of social policy is poverty reduction. Correcting large income or wealth inequalities is not an explicit policy objective. 
A full evaluation of the implementation and results of social policies based on these principles is beyond the scope of this article, but a few observations are in order.

As mentioned above, economic growth is seen as the main vehicle for poverty reduction and improvement in living standards. There is no question that economic growth is very important. Growth directly generates employment and real income for labour market participants and provides -through tax receipts- fiscal revenues for the State to finance social policy. Moreover, a growing economy is bound to ease distributional conflicts, as competing claims are over a "growing pie" rather than a zero-sum game. However economic growth also presents limitations as a mechanism to enable poverty reduction and improvement of living standards. First, the povertyreduction potential of growth depends not only on the level of growth but also its composition: it must be labour-intensive and provide greater benefits for the less-skilled segment of the labour market, and the spatial (or regional) composition of production must favour poorer regions more than others. Second, GDP (or any aggregate measure of the product) is a yardstick that omits distributive considerations. ${ }^{8}$ Third, growth of the product does not directly reach some vulnerable groups such as the elderly, children, the handicapped, or rural dwellers engaged in subsistence agriculture who are outside the labour market and form part of the dependent population. GDP statistics often under-report informal sector activities in which the lower income groups are involved. Action at the level of the family, civil society and the public sector is needed to reach these segments. Fourth, GDP is a commodity-or "opulence-based" measure of economic welfare that does not include non-market goods (such as political freedom, the psychological value of belonging to a community, etc.) or evils (environmental degradation, crime, urban congestion) which also decisively affect human well-being. Fifth, unlike traditional social policies which had a political following in the urban working class, in the powerful unions of the middle class (teachers, doctors) and in other interest groups, the new social policies have as beneficiaries poor and vulnerable groups with a weak voice and feeble political organization; this means that there are only tenuous political incentives for

\footnotetext{
${ }^{8}$ See Sen (1987) and Anand and Sen (1996).
}

active poverty reduction beyond that provided by economic growth, and this may be an important factor behind chronic poverty.

Another main element of the new strategy of social policies is targeting. The emphasis on precisely defining the beneficiary groups is a reaction to social policies that often reached, at a high fiscal cost, the non-poor (the middle class and the rich). A basic principle of targeting is to focus social policy on the poor and to avoid reaching the non-poor. ${ }^{9}$ In this context, targeting is more effective in terms of reaching the "real" poor, at a substantially lower fiscal cost than untargeted, broad-based social policy.

However targeting is not devoid of problems either. First, it makes the beneficiary a passive "victim" rather than an active agent with policy responses and choices. ${ }^{10}$ Second, there are serious problems of information and incentives. Delimiting the beneficiaries and the particular features of their socio-economic profile that need to be addressed is not easy (i.e., an information problem). Reaching the most vulnerable groups through the administrative apparatus of the State cannot be taken for granted everywhere. Moreover, some targeted groups have a more active political voice than others, thus biasing the transfer of resources to them (i.e., a problem of incentives). Political favouritism and the clientage of the most prominent groups can lead to failure to reach the neediest.

Private-sector provision and delivery of social services such as education and health is another component of a market-based approach to social policy. Private sector involvement in the social sectors can help to release financial and human resources of the State so that its efforts can be focused on the lower income groups. Privatization of social services, or their provision under concessions, seems to work well in terms of an adequate supply -in terms of quantity and quality - of education and health services for high-income and upper middle class sectors that can afford to pay for the services thus provided, but for low-income groups and the lower segments of the middle class the situation is different. As their ability to pay is low they depend on demand subsidies -such as a voucher system- for gaining access to high-cost, privately-provided social services, or else they must

\footnotetext{
${ }^{9}$ See Cornia and Stewart (1996) for an interesting discussion of two types of "errors" in targeting: the E-error (Excessive coverage, i.e., reaching the non-poor) and the F-error (Failure to reach the poor).

${ }^{10}$ In this respect, see Sen (1987) and Anand and Sen (1996).
} 
be served by the State. In addition, in the case of private health systems, the suppliers often introduce clauses that exclude the elderly, the chronically ill and those with large families from access to these programmes, although these are precisely the most vulnerable groups, which need most protection.

The coexistence of a relatively poor State-provided education and health system, along with a modern and affluent private system, creates serious problems of incentives and equity. Schoolteachers, university professors, physicians and paramedicals often have considerable incentives to work in the highly-paid private sector, thus depriving the State sector of human resources. Moreover, while some citizens will have access to first-class education and health services, others will have to make do with impoverished education, and health services provided by the State. One of the main challenges is how to guarantee good-quality, cost-efficient social services for the large segments of the population that cannot afford to pay for the services offered by the private system and must therefore be served by the State.

\section{Policies to reconcile growth, social equity and poverty reduction}

Policies designed to increase individual productivity and earning capacities are crucial for reconciling economic growth with better income distribution and less poverty. Education is a clear case in point: it endows people with greater human capital and productive potential and promotes social mobility.

The quality of education and the extent to which the poor have access to it are also important, however, but education is a supply-side policy which, in order to be effective, requires a corresponding level of demand for human resources and labour, which in turn depends on the level of effective demand and the pace of economic growth. It would be futile to have pools of educated and well-qualified people who are unemployed or under-employed.

Broadening and democratizing access to credit and the ownership of productive assets is also an equalizing, productivity-enhancing mechanism, because many latent productive projects identified and formulated by small-scale entrepreneurs and lowincome households fail to be implemented for lack of credit and finance.

The recent literature maintaining that "inequality harms growth" stresses that redistributive policies pe- nalize private investment and growth. This means that attention must be given to the way that redistribution is carried out. Capital taxation can depress profit rates and lead to slower investment; the level of taxation must be carefully monitored, as high taxation invites evasion as well as hampering saving, investment and growth. However, investment is also very sensitive to uncertainty and socio-political instability, which in turn are related to situations of severe inequality.

From this perspective, policies aimed at reducing major social inequalities can have a significant "social peace dividend" which is essential for fostering a framework conducive to investment and growth.

The promotion of economic growth must continue to be viewed as a basic engine for better living standards and poverty reduction, but it must be complemented with a greater awareness of the limits of consumption-based welfare. A healthy physical environment, economic and personal security,civic participation and political freedom are all very important dimensions of meaningful human self-realization, beyond the consumption of goods and services acquired in the market.

In addition, paternalistic social policies must be avoided. Paternalism is a defect of both traditional social policies involving broad-based subsidization in low-income countries with fiscal problems and also of social policies concentrating too much on targeting. The network of community and non-governmental organizations which has appeared in recent years in many countries is a useful bridge between individual atomization and an omnipresent State (yet with limited administrative and financial capacities). These intermediate organizations can and do play an important role in the design and management of social policy. "Civil society" is a valuable means of allocating and redistributing resources in addition to the market and the State.

Private provision of some social services can serve an useful role for the higher- and middle- income groups. It can also be a source of innovation and improved practices whose example should spread to the State-provided social services. In developing countries it is clear that the vast majority of the population needs access to good-quality education and health services, whether provided by the market, the State or society itself. The challenge is how to combine these three systems in designing and implementing effective, modern and equitable social policies. 


\section{VI}

\section{Concluding remarks}

Over the last decade or so, social policies in developing countries have been defined almost exclusively in terms of poverty reduction. A fresh look is now needed at the issue of the reduction of social inequality, as an additional means of reducing poverty and achieving other socio-economic objectives.

Analytically, the modern theory of distributive justice distinguishes between "outside factors" or "morally arbitrary" initial conditions (gender, race, initial assets, talent) and "personal responsibility" elements (effort, risk-taking attitudes) in evaluating the determinants of inequality of wealth or income in society. Social inequality is a reflection of individual differences in these two sets of wealth-creating factors.

Any broad and modern social policy needs to define a concept of equality and/or social equity. Equality of opportunities (e.g., for education, access to bank credit, property) must, if it is to be effective rather than merely formal, be accompanied by some complementary actions in the legal, constitutional and economic fields. More complex concepts, such as equality of outcomes, call for mechanisms to compensate for adverse initial conditions in terms of wealth, talent or gender.

The new theories of endogenous economic growth stress the complementarities between social equity and growth, since inequality can engender social conflict, invite taxation of physical investment and induce economic populism: all factors that ham- per economic growth. The empirical evidence seems to support these complementarities between equity (lower inequality) and higher growth rates.

The Kuznets curve, which links development levels with income distribution, suggests a trend towards lower inequality after "intermediate" levels of per capita income have been reached. Assuming that the Kuznets curve holds good -which is currently in dispute- it is important to know the plausible levels of per capita income after which a decline in inequality is to be expected, and the mechanisms that bring about that decline.

Market-friendly social policies rely on growthled poverty reduction, targeting and private sector participation in the delivery of social services. Some loose ends in this strategy are: i) insufficient awareness of the limits of commodity-based growth for reducing poverty in conditions of high inequality; ii) informational, administrative and political limitations on the ability to reach the target groups; and iii) excessive segmentation in the quality of the social services provided by the private and State sectors and the population's access to them.

Broadening and deepening of good-quality education for all, improvement of health services, and broader access to credit and ownership of productive assets by low-income households and small-scale producers are key policy measures for making longterm growth compatible with social equity.

(Original: English) 


\section{Bibliography}

Adelman, I. and S. Robinson (1989): Income distribution in development, in H. Chenery and T. N. Srinivasan (eds.), Handbook of Development Economics, vol. II, Elsevier Science Publishers B. V.

Ahluwalia, M. S. (1976): Inequality, poverty and development, Journal of Development Economics, vol. 3, No. 4, Amsterdam, North-Holland Publishing Company.

Alesina, A. and D. Rodrik (1994): Distributive politics and economic growth, Quarterly Journal of Economics, vol. CIX, No. 2, Cambridge, MA, The MIT Press.

Anand, S. and A. Sen (1996): Sustainable Human Development: Concepts and Priorities, Discussion Paper Series, No. 1., Washington, D. C., United Nations Development Programme (UNDP).

Birdsall, N. and R. Sabot (1994): Inequality as a Constraint on Growth in Latin America, Washington, D.C., Inter-American Development Bank (IDB).

Bourguignon, F. and C. Morrison (1990): Income distribution, development and foreign trade. A crosssection analysis, European Economic Review, No. 34, Amsterdam, North-Holland Publishing Company.

Clarke, G. R. (1992): More Evidence on Income Distribution and Growth, Working Paper No. 1064, Washington, D. C., World Bank.

Cohen, G. A. (1995): Self-Ownership, Freedom and Equality, Cambridge, MA, Cambridge University Press.

Cornia, G. and F. Stewart (1996): Two errors of targeting, in D. Van de Walle and K. Nead (eds.), Public Spending and the Poor, Theory and Evidence, Baltimore, The Johns Hopkins University.

Dworkin, R. (1981): What is equality? Part 1: Equality of welfare, and Part 2: Equality of resources, Philosophy and Public Affairs, No. 3, Princeton, NJ, Princeton University Press.

Deininger, K. and L. Squire (1995a): Measuring income inequality: A new data-base, Washington, D. C., World Bank, mimeo. (1995b): Inequality and growth: Results from a new data-base, Washington, D. C., World Bank, mimeo.

Fields, G. and G. Jakubson (1993): New evidence on the Kuznets curve, New York, Cornell University, mimeo.

Fishlow, A. (1995): Inequality, poverty and growth: Where do we stand?, in M. Bruno and B. Pleskovic (eds.), Annual World Bank Conference on Development Economics, vol. 1, Washington, D. C., World Bank.

Krugman, P. (1994): Peddling Prosperity, New York, W. W. Norton.

Lindert, P. H. and J. Williamson (1985): Growth, equality and history, Explorations in Economic History, No. 22, Academic Press, Inc.

Liu, H., L. Squire and H. Zou (1995): Explaining international and intertemporal variations in income inequality, Washington, D. C., World Bank, mimeo.

Marx, K. (1875, 1970): Critique of the Gotha Programme, in K. Marx and F. Engels (1970), Selected Works, London, Lawrence and Wishart.

Persson, T. and G. Tabellini (1992): Growth, distribution and politics, European Economic Review, No. 36, Amsterdam, North-Holland Publishing Company.

Rawls, J. (1971): A Theory of Justice, Cambridge, MA, Belknap Press.

Roemer, J. (1996): Theories of Distributive Justice, Cambridge, MA, Harvard University Press.

Sen, A. (1987): The Standard of Living, Cambridge, MA, Cambridge University Press.

Solimano, A. (ed.) (1996): Road-Maps to Prosperity. Essays on Growth and Development, Ann Arbor, MI, University of Michigan Press.

-(ed.) (1998): Social Inequality. Values, Growth, and the State, Ann Arbor, MI, University of Michigan Press.

- (ed.) (forthcoming): Distributive Justice and Marketled Growth, Ann Arbor, MI, University of Michigan Press. 